Матеріали Всеукраїнської науково-практичної конференчії «Актуальні питання діагностики, лікування, раціональної фармакотерапії, диспансеризації та реабілітації в практиці сімейного лікаря»

DOI

\title{
ПРЕПАРАТИ РОСЛИННОГО ПОХОДЖЕННЯ ПРИ КОМОРБІДНИХ СТАНАХ У КОМПЛЕКСНІЙ, ПРЕВЕНТИВНІЙ ТА МЕДИЧНІЙ РЕАБІЛІТАЦІї У ПРАКТИЦІ СІМЕЙНОГО ЛІКАРЯ
}

\author{
○Т. П. Гарник, Т. М. Бойчук, О. І. Волошин, Л. О. Волошина, К. В. Гарник,
}

В. О. Петріщева, І. В. Білоусова

ПВНЗ «Київський медичний університет УАНМ», Буковинський державний медичний університет

Проблема ефективності лікування та профілактики хронічних хвороб, зокрема хвороб органів дихання та загострень хронічного пієлонефриту (MKX-10: N.11.9) (ХПн) залишається актуальною на сучасному етапі розвитку медичної науки. Одним із факторів, що сприяють хронізації запального процесу органів дихання та нирок, $\epsilon$ те, що із зростанням давності перебігу ХПн та віку хворих набувають значної частоти та вираженості супутні захворювання, у тому числі і системи травлення (СТ), зокрема: хронічні гастрити (МКХ-10: К.27.3-К.29.7) (ХГ), хронічний гастродуоденіт (МКХ-10: К.29.9) (ХГД), хронічний холецистит (MKX-10: К.81.1) (XX), синдром подразненого кишечника (МКХ-10: К.58) (СПК), хронічний коліт (МKX-10: К.52.9) та дисбіоз. Відзначається розвиток споріднених патогенетичних ланок у розвитку ХПн та супутньої гастродуоденальної патології, що дозволяє визначити її як коморбідну за клінічними та метаболічними ознаками, а також за наявністю спільних інфекційних джерел (інфекційно-токсичний, інфекційно-алергізуючий взаємні впливи, зумовлені, зокрема, інфікуванням та носійством Helicobacter pylori).

Результати динамічного спостереження за пацієнтами із захворюваннями органів дихання та ХПн і коморбідними ураженнями органів СТ впродовж декількох років дозволяють стверджувати, що в окремих випадках є вплив різних зовнішніх факторів, як екологічних, так переважно і аліментарних (переїдання, незбалансоване та неякісне харчування), що можуть призводити до клінічного домінування ураження гастродуоденальної (ГДС) чи гепатобіліарної систем (ГБС) на тлі явищ ХПн та хвороб органів дихання. У більшості випадків (40-60 \%) синтетичні лікарські засоби, призначені для лікування хворих із загостреннями хронічної патології органів дихання у поєднанні з ХПн, часто $\epsilon$ провокуючими факторами щодо загострень гастро-, гепато- та ентеропатій, СПК, дисбіозу, і це зумовлює зворотний механізм посилення коморбідності перебігу захворювань. Наростаючий з віком пацієнта загальнопатологічний неспецифічний механізм стійкого метаболічного оксидативного стресу зумовлює торпідність перебігу та схильність до рецидивів будь-яких захворювань, а також погіршення переносимості синтетичних лікарських засобів.

У таких ситуаціях у лікуванні пацієнтів зі згаданими коморбідними станами слід надавати перевагу полікомпонентним лікам рослинного походження, яким властива поліфункціональна регуляторна, метаболічна, протизапальна, спазмолітична, антиоксидантна, позитивна органотропна дії.

На фармацевтичному ринку України за останні 5-10 років з'явилися ефективні вітчизняні та зарубіжні ліки рослинного походження, апробовані нами на стаціонарному та амбулаторнополіклінічному етапах у комплексній терапії, медичній реабілітації та превентивній терапії у досліджуваного контингенту хворих за період 2009-2014 рр. у 217 хворих на ХПн у період помірного загострення з коморбідними ураженнями СТ (ХГ, ХГД, СПК) та ГБС (хронічний некаменевий холецистит (XHX), дискінезія жовчовивідних шляхів (ДЖШ)) в період помірного загострення чи нестійкої ремісії.

Критеріями ефективності лікування були обрані:

- початок зменшення нефрологічної симптоматики (день);

- початок зменшення симптоматики з боку ГБС (день);

початок зменшення симптоматики з боку СТ (день);

- час настання неповної ремісії;

- частота рецидивів упродовж одного року (випадки);

- потреба в повторній госпіталізації (випадок);

- побічні ефекти (відсоток пацієнтів);

- нормалізація параметрів периферійної крові за 2 тижні лікування (відсоток від загальної кількості хворих);

- усунення явищ активації запального процесу в сечі (відсоток від загальної кількості хворих);

- позитивна динаміка при ультразвуковому обстеженні органів черевної порожнини і нирок через 1 місяць від початку лікування.

За основу оцінки ефективності лікування взяті клінічні критерії, і як допоміжні - лабораторні та ультрасонографічні. 
Матеріали Всеукраїнської науково-практичної конференції «Актуальні питання діагностики, лікування, раціональної фармакотерапії, диспансеризації та реабілітації в практиці сімейного лікаря"

При домінуванні клінічних ознак патології органів дихання застосовували препарати «Синупрет», «Бронхіпрет», «Імунопрет», при ХПн застосовували рослинні лікарські засоби - фітопрепарати «Канефрон Н», «Уронефрон», «Уролесан», «Фітоліт», а при переважанні симптоматики коморбідної патології ГДС чи ГБС (ХГ, ХГД, XX) - «|берогаст» або «Гастритол». В якості групи порівняння обрали контингент хворих, лікованих «Канефроном-Н», визнаним за ефективністю і мінімальною частотою побічних ефектів, та таким, що має велику доказову базу в Європі та Україні.

Разове та добове дозування зазначених препаратів здійснювали згідно з інструктивними вказівками. Оцінювали вплив кожного з препаратів як на ключову мішень його призначення (органи дихання, сечостатева чи травна система), так і на коморбідні патологічні процеси. У комплексному лікуванні хворих із зазначеними захворюваннями згідно з протоколом обов'язковим компонентом була антибактеріальна терапія, застосована переважно згідно з чутливістю мікрофлори сечі тривалістю не менше двох тижнів.

Результатом застосування описаних терапевтичних підходів стало пришвидшення настання неповної клінічної ремісії хвороб органів дихання, ХПн та коморбідних хронічних захворювань ГДС та ГБС (ХГ, ХГД, XX), подовження ремісії та, відповідно, зменшення частоти рецидивів, а також потреби у повторних госпіталізаціях.

Методичні рекомендації призначені для застосування у практичній діяльності лікарів загальної практики - сімейної медицини, терапевтів, нефрологів, гастроентерологів. 